This item was submitted to Loughborough's Research Repository by the author.

Items in Figshare are protected by copyright, with all rights reserved, unless otherwise indicated.

\title{
An analysis of the Chinese Football Reform of 2015: why then and not earlier?
}

PLEASE CITE THE PUBLISHED VERSION

https://doi.org/10.1080/19406940.2018.1536075

\section{PUBLISHER}

(C) Taylor \& Francis (Routledge)

\section{VERSION}

AM (Accepted Manuscript)

\section{PUBLISHER STATEMENT}

This is an Accepted Manuscript of an article published by Taylor \& Francis in International Journal of Sport Policy and Politics on 14 November 2018, available online:

http://www.tandfonline.com/10.1080/19406940.2018.1536075.

\section{LICENCE}

CC BY-NC-ND 4.0

\section{REPOSITORY RECORD}

Peng, Qi, James Skinner, and Barrie Houlihan. 2018. "An Analysis of the Chinese Football Reform of 2015: Why Then and Not Earlier?”. Loughborough University. https://hdl.handle.net/2134/36054. 


\title{
Earlier?
}

\author{
Qi Peng (Corresponding Author) \\ Manchester Metropolitan University \\ Email: Q.Peng@mmu.ac.uk \\ Postal Address: Room 4.09, Business School \\ Faculty of Business and Law \\ Manchester Metropolitan University \\ All Saints Campus, Manchester, M15 6BH \\ Telephone: +44 7397795477 (UK) \\ James Skinner \\ Institute for Sport Business, Loughborough University London \\ Email: J.L.Skinner@lboro.ac.uk
}

Barrie Houlihan

School of Sport, Exercise and Health Sciences

Loughborough University and The Norwegian

School of Sport Sciences, Oslo.

Email: B.M.J.Houlihan@lboro.ac.uk 


\title{
An Analysis of the Chinese Football Reform of 2015: Why Then and Not Earlier?
}

\begin{abstract}
In March 2015, the Chinese government issued the Overall Plan for Chinese Football Reform and Development, which aimed to develop football in China from the grassroots level to the elite level. The salient element of the plan was to separate the Chinese Football Association (CFA) from direct government control. Considering the previous failed attempts to reform the CFA, this paper asks the question 'why the reform occurred in 2015 and not earlier?' and aims to: 1) identify the potential sources of the policy change through the lens of the Multiple Streams Framework (MSF); and 2) examine the timing and conditions under which the Chinese government initiated the football reform. Public policy documents and media reports from 1993 to 2017 were collected and analysed; 17 interviews were conducted with key policy actors within the CFA and professional football clubs in varying tiers of Chinese football leagues. The findings suggest that the failure of previous policy attempts at improving Chinese football (policy stream), match-fixing scandals and the continuing under-performance of the national men's team (problem stream), the increasingly critical national mood towards football and the turnover of Presidency (political stream) combined in the mid-2010s opened a 'policy window' which facilitated this significant change. This research is the first paper to apply the MSF theory to explain the Chinese football reform that occurred in 2015. It extends the application of MSF to a different political and cultural environment and has implications for the policy-making in China.
\end{abstract}

Keywords: Football; China; policy change; Chinese Football Association; Multiple Streams Framework. 


\section{Introduction}

In the late 1970s, China adopted the national policy of Reform and Opening-up and since then the country has been in transition from a planned economy to a market economy while retaining strong central government oversight (Fan et al. 2010). The change has resulted in spectacular economic growth, yet the change has also been characterised by the slow public institutional reform, which has restricted the government's ability to react to market changes. Tian and Chen (2016) highlighted this phenomenon by noting that marketisation has generated significant progress in the Chinese economy, however, the government still plays a dominant role in all sectors. This tension between economic and political institutional structures is perceived as a bottleneck to further reform in China (Tian and Chen 2016).

Sport in China has experienced a significant transition as a result of the challenges of professionalisation and commercialisation and the government's ambition for international sporting and Olympic success. The professionalisation of football in China started in 1994 and flagged the beginning of the Chinese sport sector's transition from the state-run sport system to a market-driven sport system (Tan and Bairner 2010). However, even though professional clubs and leagues were set up in accordance with the European football league system, the CFA, the national governing body of the leagues, was not an independent governing body as it was directly controlled by the General Administration of Sport of China (GASC) (Fan and Lu 2013). Unlike the European football associations, 'all the Presidents of CFA have been highranking public officials and were appointed by GASC' (Fan and Lu 2013, p. 1642), not elected by clubs or the member organisations. For a long time, the football clubs were not involved in any high-level decision-making process in relation to the development of professional leagues. The unbalanced institutional tension caused discontent and conflict between professional clubs and the CFA. It was evident that structural reform of the sport sector was necessary (Fan and Lu 2013, Tan and Bairner 2010; Yuan 2011). To address these problems, in March 2015, the 
Chinese government initiated a program for football reform which was characterised by a new public policy entitled The Overall Plan for Chinese Football Reform and Development (Chinese State Council 2015). This brings out the aim of this paper, which is to explain why this major reform occurred at this particular time. Under the overarching aim, the two research objectives are:

1. to identify the potential sources of the policy change through the lens of the Multiple Streams Framework;

2. to examine the timing and conditions under which the Chinese government initiated the football reform

The section below describes the policy context of the reform and is followed by a discussion of the rationale for applying the Multiple Streams Framework (MSF) as a theoretical foundation for the data analysis and an overview of the research methods adopted. The findings and discussions which are structured around the five salient elements of the MSF will be presented prior to a brief summary of the contributions of this paper.

\section{Policy Context: The Overall Plan for Chinese Football Reform and Development (Reform} Plan)

The 2015 Reform Plan was radical in three ways. First, it recognised the importance of developing football at all levels. For a long time, youth football development in China had been over-shadowed by the pursuit of elite success (Fan and Lu 2012). In the Reform Plan, it explicitly stated the aim to have a significant increase in youth football participation as the midterm goal.

Second, for the first time in Chinese history, football development is prioritised as part of its national strategy. Summoned by the Vice-Premier Liu Yandong, an Inter-ministerial Joint Congress System for the Reform and Development of Football had been established to guide 
and implement the football reform from the state level. As Yu et al. (2017) observed, the new policy 'represents the actualisation of substantial central planning and sizeable resources allocations' (p. 3).

Finally, the policy initiated an institutional reform of Chinese football that constrained government intervention in football and which started with the decoupling of the CFA from the GASC. Previously, the CFA, consistent with other national or local sport associations in China, was a shadow organisation of the government whose 'systematic and mechanical power was centralised' (Yu, et al. 2015 p. 1279). The problem now confronting the CFA was how to meet the insatiable public appetite for football and leverage the commercial opportunities that were emerging from this (Gong, et al. 2015).

\section{Policy Change and the Multiple Streams Framework}

It is argued that the 2015 reform was a significant break from previous policies. While it is relatively easy to identify a policy change, it is far more challenging to explain why the change took place at the time that it did and in the form that it took (Houlihan 2005).

The MSF was employed because it was designed to answer the question of what makes an idea's time come and find explanations to why decision-makers pay attention to one issue rather than another (Kingdon 1995). This allows MSF to serve as a heuristic analytical lens to fulfil the aim of this paper. The MSF was utilised also because out of all the policy analysis theories which have built upon the western policy literature, MSF is one of the most useful frameworks to explain the critical timing under which a policy change can occur (Baumgartner 2016; Weiner 2011; Zahariadis 2007). It is worth noting here that the timing of policy making is worth investigating because 'developing an understanding of the forces that move policy formulation processes in one direction or another' allows policy practitioners to grasp the right opportunity to enable a policy change (Kingdon 1995, p. 2). It was therefore intended that, with 
this research, the policy formulation process of the Chinese football reform plan can be understood and thus provide further evidence of the effectiveness of the MSF for sport policy analysis in the Chinese context.

Not only does MSF deal explicitly with the process of agenda-setting, but it also proved to be useful when applied to the Chinese context. Xufeng Zhu (2008) has applied MSF to investigate the Chinese detention and repatriation system. He pointed out the differences in the application by concluding that value acceptability is more significant for the adoption of a policy in the Communist China where there are chances for technically infeasible policies being accepted by the government as long as they are ideologically correct (Zhu 2008). Zhou and Feng (2014) argued that MSF was applicable to China in their examination of college matriculation policy reform for children of migrant workers. Moreover, Zheng (2017) tested the usefulness of the MSF model in the Chinese elite sport studies and applied the concept of the policy window to analyse elite swimming development in China between 2000 and 2012. In addition, the MSF model chimes with the identification of some signs of a pluralist tendency in some areas of policy in China. Zhang (2017), for example, noted a growth in civic associations and concluded that China exhibited a hybrid model of state-society relations that had elements 'of both pluralism and state corporatism' (p. 14). He commented that 'policy-making has become more, albeit selectively, open to social demands and ...NGOs with financial, human, and (or) social capital resources can influence governmental policy' (2017, p. 16). This is a conclusion that Zheng, et al. (2019) considered appropriate in relation to the more commercialised areas of sport policy.

Kingdon (1995) argued that the context for and interaction between three streams: 1) problems, 2) policy, and 3) political, together with the promotion of policy entrepreneurs can open a policy window and thus influence the government agenda and policy alternatives. Each of these streams, as well as the policy window and policy entrepreneurs, will now be introduced. 


\section{Problem Stream}

Kingdon (1995) defined a problem from a three-dimensional perspective: values, comparisons, and categories. For instance, when an athlete is caught doping, it can cause uneasiness and even mistrust among the public as the integrity of sport is challenged because of a potential juxtaposition of values and beliefs that underpin sporting competition. The comparison of conditions and performances between different countries or time periods can also create problems (Zahariadis 2007). The fact of being behind of your competitor in a sport event is enough to constitute a problem for some people (Kingdon 1995, p.111). Placing a problem into one category rather than another can help define and facilitate a response to the problem in a timely and appropriate manner. For example, the categorisation of the need for community leisure facilities as a leisure issue or a health issue may influence the level of political interest and potentially attract more policy resources.

Problems are not always recognisable. For a problem to gain awareness among government officials, certain mechanisms, indicators, focusing events, and feedback needs to be in place (Kingdon 1995). Indicators, such as the cost of a programme, infant mortality rates, or highway deaths, 'can be used to assess the magnitude of a condition, as well as the scope of change' (Zahariadis 2007, p. 70). Indicators can usually be detected via routine monitoring of certain condition or investigation of a problem. A focusing event is another powerful tool to attract the attention of policymakers. For instance, a disastrous air crash may capture the attention of policymakers and encourage an investigation into the safety issue of aircrafts. Kingdon (p. 98) indicated that focusing events are likely to have a greater impact at the policy agenda when 'the problem is already in the back of people's mind'.

Alternatively, problem identification can be based on feedback which may come from the government's monitoring of programmes and the evaluation of their effectiveness (Kingdon 
1995). Feedback is important as it reflects what works and what may not, which may facilitate the policymakers to make a better decision for the next round of policy formulation and implementation.

\section{Policy Stream}

The policy stream focuses on the process of policy generation. Kingdon (1995) compared the process of policy generation to that of biological natural selection and compared policy communities to the 'primeval soup' where life came into being (p. 116). He also indicated that understanding the process of policy change provides insight into how policies are created. Although all policy proposals stand an equal chance to be selected by policymakers to form a new policy proposal (Zahariadis 2007), there are two selection criteria outlined by Kingdon (1995) that policymakers usually consider, namely, technical feasibility and value acceptability. That is, if one policy proposal is more difficult to implement than another, it is less likely to be selected; or if an idea does not align with the values which policymakers are keen on promoting at that time, it is less likely to survive the selection process.

With regard to the policy survival process, there are two relevant concepts advanced by Kingdon (1995), namely, policy evolution and policy spillover. Kingdon (1995, p.124) argued that the policy process is largely evolutionary, in which some of the ideas go through processes of 'mutation' and 'recombination' until they are ready to enter a serious decision stage. Nevertheless, there is a small number of proposals that result from a process called 'policy spillover'. Policy spillover happens when ideas pass between institutionally-unrelated policy areas (Ackrill and Kay 2011). Spillover occurs under three circumstances: 1) when politicians find there is a reward for borrowing the experience from other policy areas; 2) when the 'winning coalition' can be transferred to new issues; and 3) when an established precedent can be used to further a similar change in a different policy area (Kingdon 1995, p. 63). Ackrill and 
Kay categorised the phenomenon of spillovers into exogenous and endogenous spillovers. The main difference lies in whether there is institutional interconnection among these policy areas. If there is an internal connection institutionally, then it is endogenous spillover, otherwise, it is exogenous spillover.

\section{Political Stream}

Kingdon (1995) depicted the political stream as a series of influencers such as national mood, organised political forces, and government (legislative and administrative turnover). The concept of national mood is similar to the problem notion discussed previously. The difference is that the national mood can be either positive or negative. When the national mood is positive, instead of formulating a new policy to change the situation, policymakers would be content to take the path of the original policies without significant amendment. Therefore, a positive national mood usually does not attract as much attention as a negative national mood. The negative mood, on the other hand, can result in a problem being forced onto the agenda, particularly when the national mood continues to grow and spread (Downs 1972).

Organised political forces, such as pressure group campaigns or interest groups, are considered as another important element of the political stream that can affect the policy agenda (Zahariadis 2007). Kingdon (1995) suggested that the consensus or conflict among these political forces, which either positioned inside or outside the government, could affect the political leaders' perception and reaction to these activities, and thus affect their decisionmaking. In the case of China, which is largely a one-party political system, the Communist Party of China (CPC) often 'represents and monopolize government actions.' (Zheng 2017, p. 1252) Expressly, organised political forces are not likely to make an impact on the governmental agenda, rather, the CPC usually plays a central role in changing the overall political landscape. 
The turnover of key officials in the government often introduces new agenda items that were impossible to consider or were not considered worthy under the previous administration or leadership. In other words, the change in political stream can often provide a window for policy change. The first few years of a new administration or leadership is the prime opportunity for influencing the policy agenda (Kingdon 1995). In the Chinese political context, since it is unlikely to change the CPC's position as the ruling Party of the country in the foreseeable future, the party ideology is most likely to be reflected by the central government's policy advocates.

\section{Policy Window}

The policymaking process within organisations including the government is fluid and opportunistic (Houlihan 2005). In other words, there have to be some conditions under which an issue can become a concern for the policy-makers. Such conditions or opportunities are called 'policy windows', which allow changes, expansions or abolishment of certain programmes to take place when it opens (Kingdon 1995). Kingdon (1984, p. 173) described the functioning of the policy window as follows:

The separate streams come together at critical times. A problem is recognised, a solution is developed and available in the policy community, a political change makes it the right time for a policy change, and potential constraints are not severe...these policy windows, the opportunities for action on given initiatives, present themselves and stay open for only short periods...

Two types of policy windows for policy change were identified by Kingdon (1995), namely, the 'problem' and 'political' windows (p. 166). He suggested that a policy window can open because a problem captures the attention of policy-makers; or it opens because of a change in the political stream, such as a change of Presidency or ideology. When it comes to predictability 
of policy windows in elite sport, Zheng, et al. (2019) suggested that there is a high degree of predictability in the area of elite sport policy, most notably evidenced in the performance pressure covering each four-year Olympic cycle, and the four-year cycle of the World Cup in the case of football.

\section{Policy Entrepreneurs}

Policy entrepreneurs are 'skilled and resourceful actors who couple three streams together during open policy windows' (Ackrill, Kay, \& Zahariadis 2013, p. 873). In other words, they function as advocates for certain policy proposals, or direct the attention of policymakers to a special problem of an opportune time (Kingdon 1995). Despite of the fact that policy entrepreneurs could be from inside or outside of the government system, it is worth pointing out that 'under an authoritative regime (e.g. China), actors inside the government usually play the leading role in the decision-making process.' (Zhu and Xiao 2015, p. 3). When examining the policy processes, it seems unlikely that one single person is solely responsible for a change (Ackrill, Kay and Zahariadis 2013; Bakir and Jarvis 2017). However, it can be argued that certain individuals tend to play central roles, if not as the initiators, in the change process (Kingdon 1995).

\section{Research Methods}

This research employed a qualitative approach as it was seeking deep insight into the policy development and implementation process that was occurring in the CFA. Data were collected from secondary and primary sources to provide a richer understanding of the policy change process. The main secondary source of data was from a content analysis of strategic policy documents related to Chinese football since 1993 that were published by government departments, agencies and the CFA. A full list of these documents is presented in Table 1. In addition, media reports (in the form of documentaries and news articles) published online by 
mainstream media agencies (e.g. CCTV, Xinhuanet, Sina, China Daily and People's Daily) were collected and analysed.

\section{[Insert Table 1 Here]}

Attention was devoted to an analysis of the two 'Ten-Year' Plans for Chinese Football Development (1993-2002, 2003-2012) and the Reform Plan (2015). These policy documents were selected because: 1) they were the most fundamental policies in each stage of Chinese football development; and 2) when being compared, policy continuity and change can be identified. These sources were useful in determining the scale and nature of policy from 1993. The document collection was complemented by primary data collection. A total of seventeen in-depth, semi-structured interviews were conducted, and these included twelve completed with key senior officials in the CFA and five with professional football club managers (three in Chinese Super League and two in China League One). The profile of all the interviewees is summarised in Table 2

\section{[Insert Table 2 Here]}

These participants were selected as they were involved in the policy development process in varying capacities ${ }^{1}$; others were involved in the policy implementation process and worked closely with government agencies, the CFA or the Chinese football clubs. The interviews were completed in 2017 and assisted in gaining a deeper understanding of the policy development process and the circumstances that shaped its development. Interviewees were asked a set of similar questions that covered the following themes: 1) assessing the nature and extent of the policy change; 2) identifying the enabling factors for change; and 3) the implications of these

\footnotetext{
${ }^{1}$ Some interviewees were involved in writing early reports analysing the Chinese football development situation for the central government, which eventually became part of the Reform Plan.
} 
policies. Each interview lasted between 40 and 120 minutes. Interviews were either recorded on a digital recorder or in note form and this was dependent on the participants' preference.

The data analysis started with a translation process from Chinese to English by the lead researcher. Both primary and secondary data were subject to translation and the process was verified through back translation (Brislin 1970). The lead author translated the source language (Chinese) to the target language (English), and after this a second blind translation was conducted by another Chinese speaker who translated the English translation back to Chinese. The original and translated versions were compared to check the quality and equivalence.

Interview transcripts were analysed using the Nvivo qualitative software package. Nodes were created and categorised inductively from the data. After an initial coding, a total of 118 nodes were created. The grouping of nodes was guided by the deductive insights gleaned from the Multiple Streams Framework (Kingdon 1995). Five groups (themes) were condensed from these nodes and formed the basis for the analysis. The five themes were football policy changes; political turnover; problems in football; president and government's ambition; and the CFA decoupling from the GASC. Drawing on the content analysis of the documents and media reports identified in Table1 and the interview data generated with staff within CFA and the professional clubs, the next section will provide findings and discussion regarding the policy development process that led to the radical change that occurred in 2015.

\section{Findings}

In tracing the development of the three streams that produced the policy window in 2015, which led to the publication of the Reform Plan, it is possible to divide recent attempts of football reform into three periods. The first period, from 1993 to 2002, covers the period of the first 'Ten-year Plan' which initiated a series of changes including the professionalisation of elite level football clubs. The second period covers the years of the second 'Ten-year Plan' (2003- 
2012) and is marked by the increasing frustration at the failures of the national men's team and the emergence of corruption in the professional leagues. The final period from 2013 to 2015 marks not only the abandonment of the ten-year planning process but also a radical change in the government's approach to the oversight of a major sport. Although three stages are identified, it should be borne in mind that the process of policy formulation is often chaotic and random with a great degree of ambiguity (Houlihan 2005).

\section{Phase One: First Ten-year Plan (1993-2002)}

The first Ten-year Plan was a novelty in the history of Chinese football policy. It was formulated after the defeat of the men's national team in the qualification rounds of the 1994 Men's World Cup. This could be considered a sign of the State exploring alternative ways to develop football in China. The section of the policy which received most attention was the establishment of a professional league ( Jia A and Jia B - former titles of the current Chinese Super League and League One). It was also argued that this was a result of the overarching marketisation of Chinese economy since the $14^{\text {th }}$ National Congress of the Chinese Communist Party in 1992, which led to the commercialisation of the sport sector with football being the pilot sport (Zhang and Kang 2011).

\section{Problem Stream}

The priority of the Chinese government in the first phase was the building of a strong national team. The balance between football development at the elite level and the grassroots level, and between the interests of the professional clubs and those of the national team lacked clarity. According to the memoir of Wang Junsheng, this policy orientation, to some extent misled the professional clubs. Wang Junsheng, the Vice-President of the CFA from 1992 to 2000, argued that a major reason for the failure to qualify for the World Cup and the Olympic Games between 1992 and 2000 and the low profile of domestic football leagues, was that professional clubs 
were seeking quick success and short-term benefits while ignoring the CFA regulation that each league club must set up three reserve teams to facilitate talent-identification and development (Tan and Bairner 2010).

There was a lack of awareness of the importance of mass participation as a source of long-term talent development, as the majority of football players in the national teams were trained through the professional or elite sport school system (Chinese Football Association 1993). In addition, the tension between national and commercial interests started to emerge (Tan and Bairner 2010, p. 592). However, none of these issues surfaced as specific problems during this period.

\section{Policy Stream}

A close examination of the first Ten-year Plan indicates that the main focus of the CFA during this period was the pursuit of elite and commercial success, as the policy aims for those ten years included that:

- Chinese football should rank amongst the top Asian countries and that the men's national team should qualify for the final sixteen in the World Cup and final eight in the Olympic Games

- The women's national team should reach the top three in international competitions

- The main football clubs in Jia A should match the performance of their counterparts in other Asian countries; the number of professional football clubs should reach 20 by 2002.

It was clear that the policy priority at the first Phase was the talent development at the elite level. In addition, the introduction of a revamped professional league, as noted in a documentary (Yuan and Chen 1998) filmed by the China Central Television (CCTV 5), was 
highly successful in breaking the traditional monopoly of stronger teams and raised the level of competitiveness. The following quote from a former national team player interviewed for the documentary highlighted this:

It [the new league system] brought in a competitive mechanism. This impact was not obvious in the first two years (1993-1994) when there were so many new football clubs established but only so few players available in the market. But now [1998] it's different, more and more players could choose to join the clubs. Joining in the clubs was not always safe though, if you don't work hard enough, there will always be younger players to take your place. That's a healthy competitive environment... and it is incredible!

The first Ten-year Plan was passed by the policymakers because the policy goals were in line with the Chinese people's, or at least the Chinese politicians' interest to promote football. In other words, football commercialisation that followed the country's marketisation trend meant the national strategy of marketisation was the correct path. However, it was arguable whether introducing the commercial league system to the Chinese football system at that time was technically feasible especially when the Chinese government still retained the majority of the commercial rights in all sports.

\section{Political Stream}

Overall, the political mood, including the government and the public, was supportive during this period. The introduction of professional sport was an experimental move of the government and there was a relaxed view in terms of the impact of the policy and some uncertainty regarding the criteria to define success. As an official from the CFA commented (Yuan and Chen 1998): 
In the first year of professionalisation, we lacked the experience of managing the new system. For example, in 1994 when there were both the World Cup and the Asian Games going on at the same time, in order to enable players to participate in the Asian Games in October, we had to suspend the league matches to make sure the players get proper training as a national team. This sacrifice now seems quite unreasonable...things like this were not rare. I think the fans at that time were very tolerant and supportive partly because they saw the benefit the league brought to the national team performances.

The first phase might be considered a 'honeymoon' period, as the first few years witnessed a new commercial structure being integrated into the traditional Chinese sports system that generated a healthy competitive environment. Although the first Ten-year Plan was formulated and initiated by the CFA as the documents indicated, it is very likely that the political leader in the GASC played an important role in the decision-making, given the historical overlapping relationship between CFA and GASC. In other words, the top leaders of CFA, who also acted as political officials in the GASC, were the policy entrepreneurs to make the first ten-year plan possible. However, problems within football development began to accumulate in the later years of the first phase as corruption started to emerge due to the pursuit of political and commercial ambitions (Liang 2014). As these problems were not promptly addressed by the CFA they intensified during the second phase and were compounded by the emergence of new problems.

\section{Phase Two: Second Ten-year Plan (2003-2012)}

In 2002, during the evaluation of the first Ten-year Plan and the formulation of the new Tenyear Plan, there was little evidence of decision-makers within the CFA learning lessons from the past. There was no significant change in the second Ten-year Plan, except that the new 
policy set arguably unrealistic targets with only small adjustments on the basis of the first Tenyear Plan. At the same time, old problems from the first phase became more serious and new problems emerged in the second phase as a result of the neglect by the policy-makers. There was also evidence (comments from the mainstream media agencies as shown below) of the public becoming more frustrated and disappointed at the national team performance and calling for a more radical reform of the football governance system.

\section{Problem Stream}

Problems from the first phase, such as the neglect of football at the participation level, the reliance on the hierarchy of sports schools to produce talent rather than having a substantial participation base as the source of talent, continued into the second phase. However, new problems began to develop and became more sharply defined partly because of the country's Olympic success. Although China had achieved success on the Olympic stage, it also wanted to achieve success in the World Cup to further enhance national pride (Meier and Mutz 2018). Unfortunately, the striking underperformance of the national teams (in particular the men's team) created a problem. Failure to qualify for the 2006 and 2010 World Cups prompted another wave of debate in the football sector as well as in the government. This echoes with the argument made by Zheng et al. (2018) with regard to policy window predictability, when a situation repeats itself every four years (such as the poor performances at the World Cup), it is very likely that the condition will bring the accumulated concern of the public to the attention of policymakers. Moreover, notable progress with medal performances at the Olympic Games highlighted even more sharply the lack of success in football: many Chinese sports and disciplines (swimming, table-tennis, gymnastics, volleyball, etc.) were successful in winning medals in the Olympic Games, yet for football, as the world's most popular sport, it was consistently at the opposite end of the success continuum. 
In addition, the match-fixing problem, which was revealed in the late 1990s, became more severe during the second phase. Since 1998, when a series of indisputable match-fixing scandals were exposed by the media ${ }^{2}$, football fans started to feel disenchanted with football and this was reflected in the decline in attendance (Rao 2013). The average attendance in each Jia A game dropped from 24,300 in 1996 to 14,100 in 2002 ( $\mathrm{Li} 2015$ ). However, the inaction of the CFA at that time towards this misconduct after the media exposure led to more corruption throughout the whole professional league system during the second phase (Gong 2014). As a result, a mood of frustration and disappointment regarding the football governance swept across the country. Xinhua News Agency (The Fight against Match-fixing 2009) commented:

The (sickness within) Chinese football is beyond cure. We are calling for justice in the country to prevent football from falling dead. If the football governing bodies (GASC and CFA) are going to put on another fake show (referring to the lenient sentence imposed by CFA following the match-fixing scandal in 2001) in the 'anticorruption campaign', we won't be able to see Chinese football rise ever again!

\section{Policy Stream}

Compared with the first Ten-year Plan, there was no significant change in the second Ten-year Plan. The continuing emphasis on achieving the arguably unrealistic goals exposed the policymakers' failure to consider the policy feasibility, albeit this policy embodied their values and interests at that time. Domestically, problems such as match-fixing and illegal gambling persisted which led to the alienation of football fans (Li 2015; Rao 2013). The tension was building up among the CFA and the professional clubs and the fans. The policy introduced in

\footnotetext{
${ }^{2}$ In 2001, the 'Jia B Five Rats Incident' reported five football teams to be involved in a series of fixed matches in the final round of the Jia B League.
} 
the first phase had not solved this problem, and in the second phase, these problems became more acute.

\section{Political Stream}

It was clear that there was something wrong with the way football was governed, at all levels. It was not delivering at the grassroots level, nor at the elite level and the professional level. It was becoming apparent that the national mood was changing and the need for action was becoming apparent to policy-makers. As a consequence, strong action was taken by the GASC. For example, in 2009, to tackle the corruption occurring in football, 39 football officials and players were convicted, and heavy fines were imposed on the professional clubs who were involved. This policy was considered successful and won considerable support among the public (Poll 2011).

The second phase also witnessed the impact of the turnover of officials on the policy agenda. Chinese President Xi Jinping is a fan of football, and before his 2012 accession to the Presidency, President Xi had made known his ambition to develop football. On his official visit as the Vice-president to Germany in October 2009, he made a comment on Chinese football which was captured by the media (Lu 2009):

After the (Beijing) Olympic Games, China has made a resolution...since we can win gold medals in other sports, we should also be determined to improve football. This process, however, will take a very long time...

When President Xi took office, his ambition to improve Chinese football was even more apparent as he consistently engaged in football discussions and attended football matches and stadium tours during his state visits. 
By the end of the second phase, Chinese public opinion and the national leadership were strongly in favour of a radical change to address the problems of football national team failures, the problems that beset the professional leagues and the failure of talent development practices. The policy entrepreneurs in the second phase were somewhat the same as in the first phase, that is, the top leaders in the CFA who also senior official in the GASC finalised and implemented the second Ten-year Plan.

\section{Phase Three: 2013-2015}

Building upon the accumulated problems and failed policy attempts to improve Chinese football, in the third phase from 2013 to 2015, the Chinese government decided to abandon the previous ten-year policy process and embrace radical policy change and decouple the CFA from the GASC.

\section{The Problem Stream}

In the third phase, prior to the formulation and issuing of the 2015 Reform Plan, a comprehensive investigation into the status quo of football in China was carried out by the CFA. It was on the basis of this investigation the CFA formulated the draft for the Reform Plan. A central element of the Reform Plan was the need for the CFA to have greater autonomy. According to one interviewee, when asked why the government decided to initiate the radical change, he responded:

...the central government was determined to improve football and when the reform group investigated the reasons why Chinese football had not made significant progress despite all the efforts in the past twenty years, they asked us football professionals for advice. Some people pointed out that: 'it's not that we didn't work hard...we tried so many different ways, it is just the inappropriate institutional 
system for football development!' Therefore, the central government took our advice — if it is a problem of institutions, okay, let's change them...

The accumulation of indicators was another driving force for change. When asked why football reform has to take place in 2015 , one respondent in the CFA who was involved in the policymaking process responded:

Have you looked at the performance of us (men's teams) in the World Cup (matches) in history? It was just disastrous! We only made into the World Cup once (in 2002) and we then lost all three matches...the 2014 Brazil World Cup was just another turn of the Wheel (of fate) ...this has to change, we have to do something about it...

The feedback gained through the government's investigation into the sport sector served as another important source for problem identification. One of the most prominent pieces of evidence was the report submitted to GASC by the Central Commission for Discipline Inspection (CCDI) $)^{3}$ of the Communist Party of China in November 2014. In the report, Zhang Huawei, the leader of the inspection group, indicated that based on the investigation of sport organisations including the GASC, its affiliated units, and sport associations (including the CFA), it was found that there were some problems requiring further attention from the government. These problems included:

- Extensive game manipulation which seriously violated the principle of sporting fairness;

- The 'multiple identities' (with the overlapping attributes of a public institution, voluntary association, and a company) of many GASC affiliated organisations which led to the formation of an overcentralised governance model in the sport system. (Central Commission for Discipline Inspection 2014)

\footnotetext{
${ }^{3}$ The Central Commission for Discipline Inspection is a standing committee body set up under the Central Committee of the Communist Party of China (CPC) for managing party disciplinary inspections nationwide.
} 
The report reinforced Zhang's long-standing concern with the need to tackle the major issues confronting sport, especially the fight against corruption and the need to expand government regulation across the sport sector through institutional reform. The suggestion of institutional reform was also embedded in the 2015 Reform Plan. Indeed, in the third phase, the severity of the problems in football and the necessity of enacting policy change were finally recognised.

\section{The Policy Stream}

While the impetus for policy change had been embraced, the policy needed to survive in order for the change to occur. It is possible to argue that both policy evolution and policy spillover are significant factors facilitating the policy change in the third phase.

Through a close examination of the 2015 Reform Plan, it is apparent that the plan was partly developed from the ideas within the two CFA ten-year plans. Table 3 highlights that among the eleven guidelines outlined in the 2015 Reform Plan, ten can be traced back to the first 'Tenyear Plan'. Although some changes in policy content can be identified due to the alterations in the policy environment and the policy implementers, the evolution of policies can be identified. Taking the training of football technicians (e.g., coaches and referees) as an example, in the 1993 policy, the training of technicians was only mentioned in two sentences within the Guideline 20; however, in the second Ten-year Plan (Chinese Football Association 2003), two pages of detailed policy guidance were dedicated to the training and promotion of technicians. Yet, as seen in Table 3, the decoupling of the CFA from the government was not mentioned in the 1993-2002 Plan. It can be argued that this part of policy change is a punctuation, a dramatic change that disrupts long periods of policy continuity (Baumgartner and Jones 1993), rather than policy evolution.

\section{[Insert Table 3 Here]}


It is also proposed that there was an endogenous, rather than exogenous, spillover occurring within the policy process of football reform in China, because of the institutional interconnection among the two policy areas' (Ackrill and Kay 2011). More specifically, the decoupling of the CFA from GASC, was a policy spillover which was resulted of the liberalisation or marketisation of the economy. This proposition was echoed by football researcher Gong Bo (2014)

In the past, Chinese football was developed within the planned economy and the market was to a large extent fragmented and chaotic... Now that Chinese football has established its fundamental reform path, which is through marketisation, it is therefore important for the football practitioners to abide by the market laws (p. 225)

The Chairman of CFA Cai made a similar comment in a press conference in March 2015, where he stated:

The crucial thing to develop Chinese football in the near future is to better integrate the advantages of current sport system $\left(\right.$ Juguo Tizhi $\left.^{4}\right)$ and market economy...

To summarise, a combination of policy evolution and (endogenous) policy spillover led to a policy stream which created the conditions for a potentially radical change. Apart from that, the values that underpin the promotion of football are in line with the new Presidency and his administration's interests, whether it is for diplomatic values or nationwide health promotion.

\section{The Political Stream}

The national mood prior to the third phase was unfavourable towards previous football related policies and governance. However, there was another factor in the political stream that drove the change. The influence of the new President and his administration was significant in the

\footnotetext{
${ }^{4}$ Juguo Tizhi: A system which encompasses the full range of state activities in sports (Hu and Henry, 2017)
} 
formulation of the 2015 Reform Plan, and this influence can be identified in the policy itself. The paragraph introducing the Reform Plan emphasises the impact of President Xi on the initiation of the policy document (Chinese State Council 2015):

Since the 18th Congress of the Chinese Communist Party (CCP) was convened, the Central Committee Leadership with Comrade $\mathrm{Xi}$ Jinping as General Secretary has placed the development of football and the building up of a great sports nation as an initial task. General Secretary Xi Jinping has on several occasions pointed out that the Chinese football industry has to be developed.

When asked about the impact of the new President and his administration on the reform policy, all the interviewees thought that the new administration played a crucial role in bringing the reform of football onto the policy agenda. However, one respondent cautioned against placing too much emphasis on the role of the President in initiating policy change:

Some people say that Chinese football underwent such radical change this time only because President Xi is a big fan of football. I think this kind of statement is bit superficial. It is true that President Xi likes football, but there are more important reasons that the central government decided to initiate the reform-they saw the social, economic, political and cultural values in football... you just can't say it happens because of a person's hobby...

What this informant suggested resonated with the policy analysis literature, which indicated one individual is unlikely to be solely responsible for a change of policy agenda (Kingdon 1995). However, it was evident that President Xi and his administration as well as the top leaders in the CFA had acted as policy entrepreneurs in the initiation of the Reform Plan. 


\section{Discussion}

It is necessary to reiterate the main research question, which is to examine why the reform occurred in 2015 and not earlier. Based on the findings of this research, two reasons align with the five elements of the MSF are identified. First, the timing and conditions under which the Chinese government initiated the 2015 football reform lie in the conjunction of the three streams. Second, two policy windows together with the intervention of policy entrepreneurs enabled the radical change.

The Problem Stream. Each phase has its own problems. for instance, the problems that existed in the Phase One (1993-2002) resulted in part from distorted policy objectives. In other words, the objectives emphasised by the policymakers at that time were more oriented to elite performance success, rather than mass participation. This objective was consistently prioritised through Phase Two (2003-2012) and Phase Three (2013-2015) and contributed to the tension between national and commercial interests. This echoed with what Kingdon (1995, p. 110) suggested that a mismatch between the observed conditions and one's conception of an ideal state becomes a problem. The practice of asking professional clubs to give way to national team building by suspending league games or releasing players worsened the tension between CFA and commercial clubs; while the emphasis on the Olympic strategy over football development led to a reduction in the number of youth players (Gong 2014). Another problem existed can be considered as a result of the comparison of expectation and actual results. This is particularly evident after the Chinese teams achieved success at the Olympic stage. The repeated poor performances of the national men's team in the World Cup every four years served as another problem indicator or focusing event that drew policymakers' attention to the problem. In addition, the prevalent match-fixing in the commercial leagues throughout the first and second phases, as well as the feedback provided by the CCDI in 2014 both signalled the need for change with policymakers. 
The Policy Stream. When looking back at the Phases One and Two, many different policies to improve football have been tried by the Chinese government. There were coaches sent overseas to study football tactics in the 1950s; foreign coaches were invited to train local players in the early 2000s; and in the last three years, a large influx of foreign players has been transferred to China to play in the CSL. Most of the policies were developed in an evolutionary manner or followed a 'path dependency' strategy. However, these attempts did not result in significant improvements to the football performance of China, it was not surprising that a more radical solution would be considered. Moreover, it became clear that the problems described above were partly, if not substantially the result of the institutional structure that underpinned Chinese society. The first phase of football followed soon after the initiation of the national policy of economic marketisation. Following that problems developed because of the incompatibility of an overcentralised institutional structure with the marketisation of professional football. It took a long time for a compatible model to be developed and to adjust to the conflicts caused by asymmetric power and resource system imbalances (Gong 2014). It was not until the third phase, in 2013, when the Third Plenary Session of the 18th Central Committee of the Communist Party of China announced the radical institutional reform that enabled the policy spillover to happen, thus, a radical change of football governance became possible.

The Political Stream. From the first phase to the second phase, the national mood towards Chinese football had sourced due to the corruption problems in the commercial leagues and the poor performance of the national men's team in international competitions. Although the anticorruption campaign in 2009 managed to raise morale a little the public mood in relation to football remained rather apprehensive. However, President Xi Jinping's ambition to promote football as a national strategy resulted in a policy punctuation which responded to the public's concerns and created a more positive public mood. Both football practitioners and football fans were expecting and supportive of a radical change in the political landscape favourable to the 
development of football. In addition, the party ideology in China is considered consistent with, or more specifically, 'overlapping' with the government element; therefore, the impact of the party (CPC) ideology on the policy change can be considered less striking when compared to that of the turnover of government officials.

Policy Window. Two windows of opportunities were identified in this study, namely, a problem window and a political window. In terms of Downs' model of the issue attention cycle, Phase One should be considered to be the 'pre-problem' stage or 'issue recognition' stage (Downs 1972, p. 40). It was at Phase Two that corruption in the Chinese football spread nationwide and that the lack of progress of the national teams became apparent. At Phase Three, problems from the previous two phases accumulated, and arguably another round of disqualification for the 2014 World Cup served as the catalyst which resulted in the central government's decision to take action. Another important catalyst was the change of the Presidency and his administration. Although there had been a change of political administration at Phases One and Two and both administrations had shown interest in football development, they were not as committed to the change when compared to the commitment of the political administration of Phase Three. More importantly, the Presidency and the political administrations in Phases One and Two did not prioritise football promotion as a national strategy.

Policy Entrepreneur. During Phases One and Two, there was a number of potential policy entrepreneurs, including scholars, media and commercial sponsors but their influence was more on fostering a national mood of dissatisfaction with the current state of football rather than promoting a particular policy. It is clear that the election of President Xi was significant in the reform of the CFA in 2015, but it needs to be borne in mind that he was working within a very supportive 'political stream' and was faced with clear evidence of policy failure within the 'problem stream'. 
In summary, between 1993 and 2015, no radical policy change occurred in the Chinese football sector as the policy window did not open until 2015. In other words, the Reform Plan that occurred during the third phase was because the three streams synchronised, the window opened, and the influential role played by the policy entrepreneur (the President and his administration).

\section{Conclusion}

In contemporary China, football has largely been influenced, if not controlled, by the government. Specifically, football in China was designed primarily to serve the nation's political goals or at a later stage, economic goals rather than a result of a cultural enthusiasm for this sport. Albeit the 2015 Reform Plan was promoted as the Chinese government 'letting go' of the control of the football development, the fact that the President of the CFA still holds a senior administrative position in the GASC raises the questions whether the change occurring is still superficial? Will decentralised change occur, or will a centralised control continue?

This study applied the MSF model to investigate the Chinese agenda setting in the sport context, particularly in the football sector. It contributes theoretically by further examining the concepts of policy evolution and policy spillover, and the role these factors played in Chinese policy agenda setting. The study also has a number of implications about the policy-making in China. First, it suggests that in the Chinese context, it is important to have senior politicians in the government to act as policy entrepreneurs when a radical change is to be promoted. Second, the study indicated that the public opinion (public mood) can, to some extent, affect the government's decision to act. Thirds, it is indicated that while the Chinese government is clearly the dominant policy actor in the policy process, elements of civil society (e.g., scholars, media and sponsors) have some capacity to influence both the problem and policy stream. 
Finally, the study indicates considerable flexibility on the part of the Chinese government to experiment with different solutions and abandon failed policies. 


\section{Reference}

Ackrill, R., \& Kay, A., 2011. Multiple streams in EU policy-making: The case of the 2005 sugar reform. Journal of European Public Policy, 18(1), 72-89. doi: $10.1080 / 13501763.2011 .520879$

Ackrill, R., Kay, A., \& Zahariadis, N., 2013. Ambiguity, multiple streams, and EU policy, Journal of European Public Policy, 20:6, 871-887, DOI:

$10.1080 / 13501763.2013 .781824$

Bakir, C., \& Jarvis, D. L., 2017. Contextualising the context in policy entrepreneurship and institutional change, Policy and Society, 36:4, 465-478, DOI:

$10.1080 / 14494035.2017 .1393589$

Baumgartner, F., \& Jones, B., 1993. Agendas and instability in American politics. 1st ed. Chicago: University of Chicago.

Baumgartner, F. R., 2016. John Kingdon and the Evolutionary Approach to Public Policy and Agenda-Setting.In Zahariadis N. (Ed.) Handbook of Public Policy Agenda-Setting. Cheltenham, Edward Elgar Publishing, 53-65.

Brislin, R. W., 1970. Back translation for cross-cultural research. Journal of Cross-Cultural Psychology, 1(3), 185-216. doi: 10.1177/135910457000100301

Central Commission for Discipline Inspection of the Communist Party of China (CCDI), 2014. The $11^{\text {th }}$ CCDI Team Report to the Genenral Administration of Sport of China Retrieved from http://www.ccdi.gov.cn/special/zyxszt/2014del_zyxs/fkqk_2014del_zyxs/201411/t2014 1117_30662.html [Accessed 7 October, 2017]. 
Chinese Football Association, 1993. Ten-year Plan for Chinese Football Development (19932002), Beijing: Chinese Football Association.

Chinese Football Association, 2003. Ten-year Plan for Chinese Football Development (20032012), Beijing: Chinese Football Association.

Chinese State Council, 2015. The Overall Plan for Chinese Football Reform and Development. Retrieved September 14, 2017, from http://www.gov.cn/zhengce/content/2015-03/16/content_9537.htm

Downs, A., 1972. Up and down with ecology: The issue-attention cycle. The Politics of American Economic Policy Making. doi: citeulike-article-id:8241790

Fan, H., \& Lu, Z., 2012. From Barcelona to Athens (1992-2004): “Juguo Tizhi” and China's quest for global power and Olympic glory. The International Journal of the History of Sport, 29(1), 113-131. doi: 10.1080/09523367.2012.634987

Fan, H., \& Lu, Z., 2013. The Professionalisation and Commercialisation of Football in China (1993-2013). The International Journal of the History of Sport, 30(14), 1637-1654. doi: $10.1080 / 09523367.2013 .828710$

Fan, W., Fan, H., \& Lu, Z., 2010. Chinese State Sports Policy: Pre- and Post-Beijing 2008. International Journal of the History of Sport, 27(14/15), 2380-2402. doi: $10.1080 / 09523367.2010 .504583$

Gong, B., 2014. The Predicament and Outlet of Chinese Football from the Perspective of Civilization. Beijing: Beijing Sport University Publishing.

Gong, B., Pifer, N., Wang, J., Kim, M., Kim, M., Qian, T., \& Zhang, J., 2015. Fans' attention to, involvement in, and satisfaction with professional soccer in China. Social Behavior 
and Personality: An international journal, 43, 1667-1682. DOI:

$10.2224 / \mathrm{sbp} .2015 .43 .10 .1667$

Houlihan, B., 2005. Public Sector Sport Policy: Developing a Framework for Analysis. International Review for the Sociology of Sport, 40, 163-185. doi:

$10.1177 / 1012690205057193$

Hu, X., \& Henry, I., 2017. Reform and maintenance of Juguo Tizhi: governmental management discourse of Chinese elite sport, European Sport Management Quarterly, 17:4, 531-553, doi: 10.1080/16184742.2017.1304433

Kingdon, J. W., 1995, Agendas, Alternatives, and Public Policies. 2nd ed. New York: Longman

Li, J., 2015. Analysis of the factors affecting the attendance in Chinese Super League (Unpublished master's thesis). Beijing Sport University.

Liang, Y., 2014. The development pattern and a clubs' perspective on football governance in China. Soccer and Society, 15(3), 430-448. doi: 10.1080/14660970.2012.753540

Lu, Y., 2009. China Top Leaders Frequently Commented on the Development of Football These Days Worth attention. Retrieved October 5, 2017, from http://www.chinanews.com/ty/ty-gnzq/news/2009/10-15/1912040.shtml [Accessed 23 October 2017].

Meier, H \& Mutz, M, 2018. Political regimes and sport-related national pride: a crossnational analysis, International Journal of Sport Policy and Politics, 10:3, 525-548, DOI: $10.1080 / 19406940.2018 .1447498$

Poll Shown Near Eighty Percent of People Support the Anti-corruption in Football. 2011. 
China Youth Daily Website. Retrieved October 4, 2017, from

http://www.chinanews.com/ty/2011/12-27/3560805.shtml [Accessed 19 November 2017]

Rao, J., 2013. Study of the number of Spectators in Chinese professional league matches. Sport 13(1). ISSN:1674-151X

Tan, T.C., \& Bairner, A., 2010. Globalization and Chinese Sport Policy: The Case of Elite Football in the People's Republic of China. The China Quarterly, 203(2010), 581-600. doi: $10.1017 / \mathrm{S} 0305741010000603$

The Fight against Match-fixing in Chinese Football Has to be Strong and Thorough. 2009. Xinhua News. Retrieved from http://news.sina.com.cn/o/2009-1126/094616672179s.shtml [Accessed 5 October 2017]

Tian, G., \& Chen, X., 2016. China Reform: History, Logic and Future. 2nd ed. Beijing: China CITIC Press.

Weiner, S., 2011. How Information Literacy Becomes Policy: An Analysis Using the Multiple Streams Framework. Library Trends, 60(2), 297-311. doi: 10.1353/lib.2011.0037

Yu, D., Li, G., Liu, R., \& Su, R., 2015. Role Underplayed: Research on the Weakening Function of the All-China Sports Federation from a Historical Perspective. The International Journal of the History of Sport, 32(10), 1279-1290. doi: $10.1080 / 09523367.2015 .1056164$

Yu, L., Newman, J., Xue, H., \& Pu, H., 2017. The transition game: toward a cultural economy of football in post-socialist China. International Review for the Sociology of Sport, 1-27. doi: 10.1177/1012690217740114 
Yuan, G. \& Chen, F. (Producer), 1998. Zàì Lùshàng-Zhōngguó Zúqiú Zhè Jǐ Nián [Enroute-the Chinese Football] (Documentary). CCTV, Beijing. Retrieved from http://www.bilibili.com/video/av6643809/index_6.html\#page=1 [Accessed 12 December 2017].

Yuan, Z., 2011. Topdown: an Innovative Choice for the Reform and Development of Chinese Football. In: Proceedings of the 8th International Conference on Innovation and Management, November 30-December 2, Kitakyushu. Japan: Yamaguchi University $777-782$.

Zahariadis, N., 2007. The Multiple Streams Framework: Structure, Limitations, Prospects. In: Paul A. Sabatier Ed. Theories of the Policy Process. 2nd ed. Boulder, Colorado: Westview Press, 65-92.

Zhang, G. \& Kang, L., 2011. The Dilemma of China Football Institutional Reform. Journal of Physical Education, 18 (2).

Zhang, C., 2017. Nongovernmental Organizations' Policy Advocacy and Government Responsiveness in China. Nonprofit and Voluntary Sector Quarterly, 1-22. doi: $10.1177 / 0899764017705735$.

Zheng, J., 2017. A policy analysis of the development of elite swimming in China between 2000 and 2012: A national team perspective. The International Journal of the History of Sport, 34(12), 1247-1274. DOI: 10.1080/09523367.2018.1432599.

Zheng, J., Chen, S., Tan, T. C., \& Lau, W. C., 2018. Sport policy in China (Mainland). International Journal of Sport Policy and Politics, 1-23. doi:10.1080/19406940.2017.1413585.

Zheng, J., Chen, S., Tan, T. C., \& Houlihan, B. 2019. Sport Policy in China. Abingdon: 
Routledge.

Zhou, N., \& Feng, F., 2014. Applying Multiple Streams Theoretical Framework to College Matriculation Policy Reform for Children of Migrant Workers in China. Public Policy and Administration Research. ISSN 2224-5731(Paper) ISSN 2225-0972(Online). Vol.4, No.10, 2014

Zhu X., 2008. Strategy of Chinese Policy Entrepreneurs in the Third Sector: Challenges of “'Technical Infeasibility”. Policy Sciences. 41:315-334 DOI: 10.1007/s11077-0089070-2

Zhu, Y., \& Xiao, D., 2015. Policy entrepreneur and social policy innovation in China. The Journal of Chinese Sociology 2:10. DOI 10.1186/s40711-015-0012-z 
Table 1: A List of Documents for Data Analysis

\begin{tabular}{|l|c|}
\hline \multicolumn{1}{|c|}{ Documents } & Sources from \\
\hline The Overall Plan for Chinese Football Reform and Development & GASC \\
\hline (2015.3) & CFA \\
\hline 'Ten Year' Plans for Chinese Football Development (1993-2002, 2003- & CFA \\
\hline Chinese Football Mid- and Long-Term Development Plan (2016-2050) & GASC\&CFA \\
\hline Chinese Football Association Statutes (2003, 2005, 2014, 2015, 2016) & CFA \\
\hline Chinese Football Association Annual Financial Report (2017) & CFA website \\
\hline Articles related to Chinese football, CFA, GASC and Chinese sport & Documentaries, \\
system & Media reports, \\
& News articles \\
\hline
\end{tabular}


Table 2 A Distribution of Interviewees in the Study

\begin{tabular}{|c|c|c|c|}
\hline Organisations & Interviewees & Number & Details \\
\hline \multirow[t]{11}{*}{$\begin{array}{l}\text { The Chinese } \\
\text { Football Association }\end{array}$} & $\begin{array}{l}\text { General Administration } \\
\text { Department }\end{array}$ & 1 & \multirow{11}{*}{$\begin{array}{l}\text { Due to confidentiality } \\
\text { reasons, the names and } \\
\text { positions will not be } \\
\text { revealed here. All } \\
\text { interviews were conducted } \\
\text { at the meeting offices of } \\
\text { each departments between } \\
\text { March and May } 2017 .\end{array}$} \\
\hline & $\begin{array}{l}\text { International Relations } \\
\text { Department }\end{array}$ & 1 & \\
\hline & $\begin{array}{l}\text { Planning and Legal } \\
\text { Department }\end{array}$ & 2 & \\
\hline & $\begin{array}{l}\text { Communication } \\
\text { Department }\end{array}$ & 1 & \\
\hline & Market Department & 1 & \\
\hline & $\begin{array}{l}\text { Community Development } \\
\text { Department }\end{array}$ & 1 & \\
\hline & $\begin{array}{l}\text { Youth Football } \\
\text { Department }\end{array}$ & 1 & \\
\hline & $\begin{array}{l}\text { Event Management } \\
\text { Department }\end{array}$ & 1 & \\
\hline & $\begin{array}{l}\text { Women's Football } \\
\text { Department }\end{array}$ & 1 & \\
\hline & $\begin{array}{l}\text { National Team } \\
\text { Administration Department }\end{array}$ & 1 & \\
\hline & Professional League Office & 1 & \\
\hline \multirow{5}{*}{$\begin{array}{l}\text { Commercial football } \\
\text { clubs }\end{array}$} & Guangzhou R\&F F.C & 1 & \multirow[t]{6}{*}{ Idem } \\
\hline & Beijing Guo'an F.C & 1 & \\
\hline & Jiangsu Suning F.C & 1 & \\
\hline & Hangzhou Greentwon F.C & 1 & \\
\hline & Shenzhen F.C & 1 & \\
\hline Total & & 17 & \\
\hline
\end{tabular}




\begin{tabular}{|c|c|}
\hline $\begin{array}{l}\text { The Overall Plan for Chinese Football } \\
\text { Reform and Development (2015) } \\
\text { (adaption) }\end{array}$ & $\begin{array}{l}\text { Ten-Year Plan for Chinese Football } \\
\text { Development } \\
(1993-2002) \text { (adaption) }\end{array}$ \\
\hline $\begin{array}{l}\text { Guideline1: The general requirements and } \\
\text { main objectives of the reform }\end{array}$ & $\begin{array}{l}\text { Guideline } 6 \text { : The general requirements and } \\
\text { main objectives of the next ten years }\end{array}$ \\
\hline $\begin{array}{l}\text { Guideline 2: Reform (decoupling) of the } \\
\text { Chinese Football Association }\end{array}$ & I \\
\hline $\begin{array}{l}\text { Guideline 3: Improvement and reform of } \\
\text { the structure and management model of } \\
\text { professional football clubs }\end{array}$ & $\begin{array}{l}\text { Guideline 2: Establish and perfect the } \\
\text { structure and management model for football } \\
\text { clubs }\end{array}$ \\
\hline $\begin{array}{l}\text { Guideline } 4 \text { : Improving the football } \\
\text { competition system and professional league } \\
\text { system }\end{array}$ & $\begin{array}{l}\text { Guideline } 11 \& 16 \text { : Establish a new football } \\
\text { competition system and league system }\end{array}$ \\
\hline $\begin{array}{l}\text { Guideline 5: Reform and promoting the } \\
\text { development of school football }\end{array}$ & $\begin{array}{l}\text { Guideline 13\&14: Construct football pitches } \\
\text { and bring football into schools; build the } \\
\text { youth football development system }\end{array}$ \\
\hline $\begin{array}{l}\text { Guideline 6: Develop the popularity of } \\
\text { community football }\end{array}$ & $\begin{array}{l}\text { Guideline 13: Construct football pitches and } \\
\text { bring football into schools }\end{array}$ \\
\hline $\begin{array}{l}\text { Guideline } 7 \text { : Improve the promotion system } \\
\text { of football technicians }\end{array}$ & $\begin{array}{l}\text { Guideline 20: Enhance research and } \\
\text { application of football theories and } \\
\text { technology }\end{array}$ \\
\hline $\begin{array}{l}\text { Guideline 8: Promoting the reform and } \\
\text { development of the national football team }\end{array}$ & $\begin{array}{l}\text { Guideline 18: Improve the whole } \\
\text { performance of national teams }\end{array}$ \\
\hline $\begin{array}{l}\text { Guideline 9: Strengthen the construction } \\
\text { and management of football pitches }\end{array}$ & $\begin{array}{l}\text { Guideline 13: Construct football pitches and } \\
\text { bring football into schools }\end{array}$ \\
\hline $\begin{array}{l}\text { Guideline 10: Optimize investment } \\
\text { mechanisms }\end{array}$ & $\begin{array}{l}\text { Guideline 12: Develop and expand the } \\
\text { football market }\end{array}$ \\
\hline $\begin{array}{l}\text { Guideline 11: Strengthen the government } \\
\text { leadership in promoting and developing } \\
\text { football }\end{array}$ & $\begin{array}{l}\text { Guideline 20: Enhance the promotion and } \\
\text { diplomacy of football and create a positive } \\
\text { environment for Chinese football } \\
\text { development }\end{array}$ \\
\hline
\end{tabular}

